\title{
Polislik Perspektifinden Dijital Misenformasyon ve Dezenformasyon: Covid-19 Örnek Olayı Bağlamında Bir Analiz
}

DOI: $10.26466 /$ opus.783266

$*$

\author{
Atalay Bahar* \\ * Dr. Polis Başmüfettişi, Emniyet Genel Müdürlüğü, Teftiş Kurulu Başkanlığı, Ankara \\ E-Posta: atk199@hotmail.com \\ ORCID: $\underline{0000-0002-3146-1833}$ \\ Öz
}

Tarihte insan sağlığını tehdit eden birçok salgın görülmüş, Covid-19 da toplumu derinden etkileyen bir pandemi biçimi olarak ilan edilmiştir. Kalitatif ve gözleme dayal veriler elde edilen bu betimsel alan araştırmasında, Covid-19 salgınının tespit edildiğ 11 Mart 2020 ve yeni normalin başladığı 1 Haziran 2020 tarihleri arasında, suça dönüşen misenformasyon ve dezenformasyon vakaları ele alınmıştır. 28 misenformasyon ve dezenformasyon içerikli Twitter paylaşımı, mesleki deneyime sahip polis uzmanlarınca analiz edilmiş ve suç kapsamında değerlendirilmiştir. Misenformasyon ve dezenformasyonların içeriği, üretim motivasyonu ve önlenmesine yönelik dijital polisliğin katkısı ortaya konmaktadır. Manipülasyon ve provokasyon içerikli paylaşımları başlatanların ve yayanların, gerçek dünyada yeni suçluların oluşmasına da öncülük ettikleri görülmektedir. Covid-19 salgınıyla mücadelenin temel kriteri olarak belirlenen yeni normal koşulların, gecikmeksizin Twitter platformu kullanım sistematiğine de uyarlanması gerekmektedir. Dijital ortamların ara yüzlerinde resmi kurumların da paydaş olabileceği bir "Güvenlik Portalı" oluşturulması, bu türden paylaşımlarla mücadelede etkili olacağı değerlendirilmektedir. Etiketleme yapılan suç ilintili paylaşımların ihbar niteliği taşıması ve son kullanıcıyla etkileşim să̆lanması amacıyla, iletilerin doğrudan Güvenlik Portalına gönderilmesini sağlayacak şekilde bir düzenleme yapılması da kullanıcıları çözüm ortă̆ı haline getirecektir. Milyonlarca kullanıcıyı sanal devriye operatörüne dönüştürebilecek bu düzenleme; yanlı̧̧, tahrif edilmiş ve aldatıcı bilgilerle toplumsal yaşamı olumsuz etkileyen, kitleleri mobilize eden ve kaos oluşturmayı hedefleyen paylaşımlara, gecikmeksizin ulaşılmasına ve hukuksal işlemlerin yapılmasına olanak sağlayacaktır.

Anahtar Kelimeler: Dijital Polislik, Dijital Medya, Misenformasyon, Dezenformasyon, Yeni Normal 


\title{
Digital Misinformation and Disinformation from a Policing Perspective: An Analysis in the Context of the Covid-19 Case Study
}

\begin{abstract}
Covid-19 has been declared as a form of pandemic that deeply affects the society, with many epidemics threatening human health in history. In this descriptive field study, which obtained qualitative and observational data, misinformation and disinformation cases that turned into crime between March 11, 2020, when the Covid-19 outbreak was detected, and June 1, 2020, when the new normal began, were discussed. 28 Twitter posts containing misinformation and disinformation were analyzed by police experts with professional experience and evaluated as a crime. The content of misinformation and disinformation, production motivation and the contribution of digital policing towards its prevention are revealed. It is seen that those who initiate and spread posts containing manipulation and provocation also lead the formation of new criminals in the real world. The new normal conditions, which are determined as the basic criteria for combating the Covid-19 epidemic, need to be adapted to the Twitter platform usage system without delay. Establishing a "Security Portal" where official institutions can be stakeholders at the interfaces of digital media is considered to be effective in combating such sharing. Making an arrangement to ensure that the messages are sent directly to the Security Portal in order to ensure that the tagged crimes related posts have the nature of notification and interact with the end user will also make the users solution partners. This arrangement, which can turn millions of users into virtual patrol operators; It will enable access to the posts that negatively affect the social life, mobilize the masses and aim to create chaos with false, falsified and deceptive information, to be accessed without delay and legal proceedings.
\end{abstract}

Keywords: Digital Policing, Digital Media, Misenformation, Disinformation, New Normal 


\section{Giriş}

Günümüzde bilgi ve habere ulaşılmasında görülen dijital hareketlilik, paradigmal değişikliğe neden olmaktadır. Kışkırtma potansiyeli yüksek, sosyal fay hatlarını hedef alan, sahte ancak inanılırlığı yüksek kurgulanmış haberlerin, anonim ya da sahipli hesaplardan yayılımı, sosyal mühendislik kapsamında değerlendirilmektedir (Eren ve Aydın, 2014, s.202). Misenformasyon kapsamandaki iletiler, kullanıcılar tarafından gerçek kabul edilerek, kaynağı önemsenmeden paylaşılmaktadır. Dezenformasyon paylaşımları ise; tahrif edilmiş veya gerçek dışı bilgi, eksik ya da taraflı paylaşımlardan oluşmaktadır. Bu içerikler, manüplatif özellikleriyle kullanıcılarda istenilen ve beklenen algılarını oluşmasını hedeflemektedir. Sosyal mühendisliğin alt bileşenleri olarak dezenformasyon ve misenformasyon; bireyleri, grupları, toplumu beklenen tutum ve davranışları sergilemelerinde oldukça etkili olmaktadır. Provokasyon, tahrik, kurumsal ve bireysel tehdit amaçlı paylaşımları başlatanlar doğrudan suçlu oldukları gibi, iletileri yayanlar yeni suçluların oluşmasına da öncülük etmektedirler. Temel parametre, paylaşımların mevcut yasalara göre konusu suç oluşturan eylemlerden olmasıdır. Toplumsal düzen, istikrar ve kişi güvenliğini tehdit eden bu paylaşımlardan etkilenen kamuoyu, kurum ve gerçek şahıslar dezenformasyon ve misenformasyon mağduru olmaktadır.

Covid-19 salgınının etki alanının genişlemesi ve vaka sayısının artışı, dijital medyada panik ve karamsarlığa neden olan mesajların paylaşılmasına neden olmaktadır. Bu sürecin ortaya çıardığı belirsizlik yoğun bir bilgi kirliliği oluşturmakta, kaynağı ve özgünlüğü dikkate alınmadan mevcut bilgiler platformlarda paylaşılmaktadır. Çoklu sanal ortamlardaki gerçekliği kanıtlanmamış istatiksel verilerin ve tedavi yöntemlerinin, korku ve endişe ile dolaşıma sunulması, durdurulması oldukça güç olan misenformasyonu ve dezenformasyonu beraberinde getirmektedir (Kayır, 2020). Covid-19 hakkında paylaşılan misenformasyon ve dezenformasyon içerikli paylaşımların, sosyal medya ağlarında yüksek ölçekte yer bulması, toplumsal tedirginliğin yayılmasında önemli bir faktör olarak ortaya çımaktadır.

Araştırmada Covid-19 salgınıyla ilgili paylaşımlardan, 11 Mart-1 Haziran 2020 tarihleri arasında suça dönüşen misenformasyon ve dezenformasyon vakaları ele alınmaktadır. Kalitatif ve gözleme dayalı veriler elde edilen bu betimsel alan araştırması, Covid-19 vakasının tespit edildiği ilk gün ile yeni 
normalin başladığı ilk gün arasındaki tarihleri kapsamaktadır. Polis operasyonları sonucunda ulaşılan İstanbul merkezli vakalar ile sınırlandırılan çalışmada, suça dönüşen misenformasyon ve dezenformasyonların içeriği, üretim motivasyonu ve önlenmesine yönelik dijital polisliğin katkısı ortaya konmaktadır. Bu amaç doğrultusunda suç kapsamında değerlendirilen, 28 misenformasyon ve dezenformasyon içerikli Twitter paylaşımı, İstanbul Emniyet Müdürlüğü, Siber Suçlarla Mücadele Şube Müdürlüğünde görevli mesleki deneyime sahip uzmanlarla, odak grup görüşmesi tekniği ile analiz edilmektedir.

Odak grup görüşmeleri ile misenformasyon ve dezenformasyon suçlar1nın toplum güvenliği bağlamında etkilerinin ortaya konulmasına yönelik önemli verilere ulaşılmıştır. Dijital ortamlarda suçun önlenmesi ve gerçekleşen suç hakkında gerekli işlemlerin yapılması amacıyla, gözlem ve takiple sanal devriye görevi yapılmaktadır. Siber teknolojiler geliştikçe, sanal ortam açıklarından yararlanarak siber suçlar da çeşitlenmektedir. Gerçek dünyanın asayişe ve topluma müessir suçları, dijital mecralarda bireysel ve örgütlü olarak işlenmektedir. Gündem oluşturan her türden olay kötüye kullanılabilmektedir. Covid-19 salgını kapsamında misenformatik ve dezenformatik suçları örneklem olarak alan bu çalışma, bir yönü ile de dijital ortamların denetimsiz ve kontrolsüz yapısına da dikkat çekmektedir.

Misenformasyon ve dezenformasyon içerikli paylaşımlar geri dönülmez sonuçları da beraberinde getirmektedir. Koronavirüsten korunmak amaciyla saf alkol içip hayatını kaybedenlere, salgının önemli bir sebebi olarak gösterilen baz istasyonlarının yakılmasına ve virüs taşıdığına dair dijital dedikodularla hedef alınan şahısların taşlanmasına kadar uzanan bir etkilenme süreci yaşanmaktadır (Somer ve Öztürk, 2020). Bu bağlamda misenformasyon ve dezenformasyon suçları doğal hayatın akışında doğrudan zarar verdiği gibi, paylaşıldıkça büyüyen mağduriyetler oluşturabilmektedir. Bu Covid 19 pandemisinin ile mücadeleyi olumsuz etkileyen asılsız ve maksatlı infodemic paylaşımlar, toplumsal bir koronafobi oluşumunda önemli rol oynamaktadır.

Çalışmada İstanbul Emniyet Müdürlüğü Siber Suçlarla Mücadele biriminde görevli uzman personel ile gerçekleştirilen odak grup görüşmeleriyle, misenformasyon ve dezenformasyon suçlarının toplumsal etkileri değerlendirilmiştir. Kitlesel hareketleri teşvik eden manüplatif paylaşımların, gerçek dünyaya da yansiyarak telafisi güç sonuçlar oluşturabileceği görülmektedir. 
Covid-19 salgınıyla mücadelenin temel kriteri olarak belirlenen yeni normal koşulların, gecikmeksizin dijital medya kullanım sistematiğine de uyarlanması gerekmektedir. Suça dönüşen misenformasyon ve dezenformasyonların yadsınamaz kelebek etkisini ele alan bu özgün çalışmanın, alanyazına bir katkı sağlayacağı düşünülmektedir.

\section{Misenformasyon ve Dezenformasyona Yönelik Kavramsal Bir Çerçeve}

Dijital ortamda, sıklıkla misenformasyon ve dezenformasyon içerikli paylaşımlara rastlanmaktadır. Kirlenmiş bilgi ve çarpıtılmış haberler ile gündem oluşturan ve kullanıcılarda endişe uyandıran, iki sanal ortam olgusu arasında yakın ilişki bulunmaktadır. Sanal ağlarda paylaşım biçimlerine, kaynağın güvenilirliğine ve kullanıcıların algılarına göre tasnif edilmektedir. Ancak sanal ortamın karmaşık yapısı misenformasyon ve dezenformasyon kavramları hakkında konsensüs oluşumunu engellemektedir. Bu konudaki çalışmalar; ağ üzerindeki kaynağın belirginliği, bilginin doğru ya da yanlışlığının tespiti, kasıtlı ve kasıtsız olarak dolaşıma sunumu ekseninde sürdürüldüğ̈ü görülmektedir.

Misenformasyon terimin çeşitli şekillerde tanımlanmakta ve yorumlanmaktadır. Wardle ve Derakhshan (2017), misenformasyonu yanlış ancak zarar vermek amaciyla üretilmeyen bir bilgi olarak betimlenmektedir. Zollo ve Quattrociocchi (2018), ispata muhtaç söylentilerin yayılması olarak tanımlarken, Scheufele ve Krause (2019), kasıtsız olarak paylaşılan yanlış bilgi şeklinde ifade etmektedir. Kavaklı (2019), başka bir bakış açısıyla misenformasyonun, dezenformasyona yakınlığını, bilginin eksik ya da taraflı olarak verilmesiyle açıklamaktadır. Del Vicario ve arkadaşları (2016), araştırmalarında dijital misenformasyonu algısını, kullanıcıların sosyal ve bilişsel konumları ile açıklamaktadır.

Alanyazında dezenformasyon tanımlamalarının, misenformasyona göre daha belirgin ve açıklayıcı olduğu görülmektedir. Diğer bir ifade ile dezenformasyon, dijital ortamlarda kolay farkedilmektedir. Marwick ve Lewis (2017), sosyal medyadaki komple teorilerini ve propaganda amaçlı paylaşımları dezenformasyon olarak nitelendirmektedir. Fallis (2015), dezenformasyonu; aldatıcı reklamlar, fotoğraflar, sahte belgeler, sahte web siteleri ve manipüle edilmiş haberler ile tüm sektörleri yanlış yönlendiren paylaşımlar şek- 
linde özetlemektedir. Fetzer (2004), ise daha kesin bir ifade ile dezenformasyonu; yanıltıcı, aldatıcı ve karışıklığa neden olan yalan paylaşımlar biçiminde tanımlamaktadır.

Çalışmadaki örneklemlere kaynaklık etmesi bakımından, dijital ortamlarda görülen misenformasyon ve dezenformasyon kavramların, literatürdeki tanımlamalardan da yararlanarak özgün bir şekilde açıklamak gerekmektedir. Bilişim sistemlerinde paylaşılan misenformasyon kapsamandaki bilgi, kullanıcılar tarafından gerçek olarak kabul edilmekte ancak kaynağı önemsenmemektedir. Maksatlı olarak tahrif edilmiş veya gerçek dişı bilgi, kullanıcilar tarafından sanal ortamlarda; eksik, yanlı veya yanlış olarak iletilmektedir (Kuklinski, Quirk, Jerit, Schwieder ve Rich, 2000, s.790). Genel kasit amaçlanmamakla birlikte, gerçek bilgi zarar görmekte ve gölgelenmektedir.

Sanal evrende dezenformasyon içerikli paylaşımlar, genellikle anonim bir hesaptan ya da farklı bir profile bürünerek yapılmaktadır. (Bekiroğlu ve Hülür, 2016, s.150) Dezenformasyon içerikli paylaşılan bilgi gerçek değildir. Bilgi kasıtlı ve kullanıcıları aldatmaya yönelik olarak üretilmektedir (Lanoszka, 2019, s.230). Sosyal medya platformlarında manüplatif ve propaganda içerikli paylaşımlar dezenformasyon olgusu işaret etmektedir. Dezenformasyon çoklu sanal ortamlarda bireylere, kurumlara devletlere zarar vermek için dolaşıma sunulan sahte haberlerin yaygınlaştırılması ile de ortaya çıkmaktadır (Botosova, 2019, s.108). Bununla birlikte yasadışı suç organizasyonları ve terör örgütlerinin, kitleleri mobilize etmek ve kaos oluşturmak amaciyla sahte veri, görüntü, video gibi paylaşımları önemli dezenformasyon faaliyetleri arasındadır.

Misenformasyon ve dezenformasyon sonuçları itibariyle benzeşmektedir. Sosyal ağlarda; sosyo-kültürel, sağlık, ekonomi siyaset, spor gibi tüm ilgi alanlarına yönelik aslı tahrif edilmiş, yanlış ya da kurgulanmış iletiler bu kapsamda değerlendirilmektedir (Kshetri ve Voas, 2017, s.11). Bireysel ya da örgütlü bir şekilde gerçek olmayan bilgiyi, toplumu etkilemek ve manipüle etmek üzere dolaşıma sunanlar, dezenformasyon kaynağını oluşturmaktadır, Bu iletilerin gerçekliğine inanıp ya da gerçekliğini sorgulamayıp paylaşanlar ise misenformasyon kaynağı haline gelmektedir. Kullanıcılar tarafından özen gösterilmeden doğrudan paylaşılan bilgi dolaşımdaki kullanıcıları yanlış yönlendirmekte, şiddeti artan toplumsal reflekslerin oluşmasına neden olmaktadır. A $\breve{g}$ sistemlerinde dayanağ 
paylaşılması, kullanıcıları bilinçli ya da bilinçsiz olarak siber suçun failleri haline getirmektedir (Erkan ve Ayhan, 2018, s.207). Dijital ortamda eksik ve yanlış bilgilerin iletimi ya da isteyerek ve bilerek dolaşıma sunulmasıyla algılar yönetilmekte, istendik toplumsal tepkiler hedeflenmektedir.

Misenformasyon ve dezenformasyon, toplumun ilgisini çeken tüm güncel konularda görülmektedir. Ekonomi, eğitim, güvenlik, sağlık, sanayi, enerji, spor, güvenik, iç politika ve uluslararası ilişkiler gibi alanlarda, kullanıcılar medya okuryazarlığı ölçüsünde ve gerçeklik anlayışları doğrultusunda misenformasyon ve dezenformasyonun etkisi altında kalmaktadır. Birçok kullanıcının aynı iletiyi paylaşması, içgüdüsel olarak iletinin doğru olarak kabul edilmesine neden olmaktadır. Ayrıca kullanıcılar takip ettikleri siteler, gruplar ve platformlarda, kendi perspektiflerinden yorumlar yaparak domino etkisi ile iletilerin tesirini arttırılmaktadır.

Oxford Dictionary tarafından 2016'da y1lın kelimesi seçilen post-truth (gerçek- sonrası) kavramı, misenformasyon ve dezenformasyon içeriklerinin çevirim içi yayılım hızının nedenini açıklar niteliktedir. Bu yeni kavram, dijital gündemin objektif hakikatten daha çok, kişisel duygu ve inançlar tarafından belirlendiğini ifade etmektedir (Oxford Learner's Dictionaries, 2020; Güven, 2020, s.22). Sanal dünyada sunulan iletiler, mutlak doğrudan ziyade, göndereni tarafından gerçek olarak hissettirilen olgulardan oluşmaktadır (Özcan, 2018, s.2). Dolaşım oranı arttıkça, paylaşımda bulunanlarca gerçeklik önemsizleşen bir niteliğe dönüşmektedir. Post-truth kavramının ortaya çıkardığı yeni gerçeklik olgusu, sanal iletişim uygulamalarında aktif olan kullanıcıları, sonuçlarını düşünmeksizin paylaşımda bulunmaya yöneltmektedir (PR Outletplus, 2020). Dezenformatik ileti, kullanıcı duygu ve düşünceleri ile örtüşmesi halinde, misenformatik olarak paylaşıma sunulmaktadır.

Bu bağlamda çevrimiçi platformlarda sosyal ve siyasal maksatla dezenformasyon ve misenformasyonlarla kamuoyunun hedeflenen doğrultuda yönlendirildiğine dair çeşitli örnekler bulunmaktadır. Paylaşımlar, gerçekleştirilmek istenen maksada göre şekillenmektedir. Sahte Rus menşeili hesaplar tarafından gerçekleştirilen dezenformasyon ve geniş katılımlı misenformasyonlarla, Donald Trump'ın 2016'da Başkan seçilmesinde önemli bir rol oynadığı iddia edilmektedir. Yakın tarihli sanal ağ dezenformasyonlarından biri de sını ötesi operasyonlarında ortaya çkmıştır. Türkiye'nin güney sınırında oluşturulmaya çalışılan terör koridorunu yok etmek, bölgeye barış ve huzur 
getirmek amacıyla 2019'da yapılan Barış Pınarı Harekatı aleyhine, terör örgütü yanlılarınca dijital platformlarda yürütülen dezenformasyon girişimlerinde, Suriye'deki çatışmalardan kaçan sivillerin görüldüğü fotoğraflar, harekat sırasında çekilmiş gibi gösterilmektedir (Anadolu Ajansı, 2019).

Dijital ortamın popülist söylemi ve irrasyoneliteye açıllı̆ı dezenformasyon ve misenformasyonu kolaylaştırırken, global politikaları ve sosyal yaşamı önemi ölçüde etkilemektedir. Hızlı bir şekilde hastagler oluşturularak sosyal medya ortamlarını sunduğu beğeni, yorum, mesaj, görüntü gibi özellikler etkin olarak kullanmaktadır (Ceng, 2018, s.673). 2013 yılında hashtag formatlarında yapılan dezenformasyon ve misenformasyon paylaşımları ile örgütlenen Gezi Parkı eylemleri esnasında asılsız bilgi, resim ve video kullanılmıştır. Yabancı bir ülkede bot motorundan yaralanan bir gencin Türkiye'deki gösteriler sırasında panzerle ezildiği, binlerce polisin istifa ettiği, köpeğe bile biber gazı sıkıldığı, polislerin ilaçı su kullandığı, eylemlerin 48 saat daha devam etmesi durumunda Anayasa Mahkemesinin hükümeti düşürebileceği, eylemcilere karşı portakal gazı kullanıldığı, şeklinde kitlesel hareketlenmeyi hedefleyen yalan paylaşımlar yapılmıştır (Eren ve Aydın, 2014, s.204).

Dijital mecranın suç oluşturan dezenformasyon ve misenformasyon faaliyetleri, siber güvenlik ihlali olarak değerlendirilmektedir. Bu kapsamda yasal prosedüreler işletilmekte ve failler tespit edilmektedir. Bilişim sistemlerindeki bu türden paylaşımlar, hukuksal mevzuatta suç sayılan fiiller arasında değil ise doğrudan siber suç olarak nitelendirilmemektedir. Mağdurların şikayetleri üzerine görevli birimlerce, adli ve idari işlemler gerçekleştirilmektedir. Bu kapsamdaki iletilere karşı filtre görevi üslenen haber doğrulama platformları bulunmaktadır. Türkiye'de dezenformasyon ve misenformasyon paylaşımlarının gerçekliğini kontrol eden Doğruluk Payı, Yalansavar, Teyit gibi web siteleri, yanıltıcı ve yanlış yönlendirmelere odaklanmaktadır (Yegen, 2018, s.105; Kavakl1, 2019, s.665). Dijital ortamda sosyal tehlike ve manipülasyon içerikli paylaşımlara yönelik çalışmalar yapmaktadırlar.

\section{Suçun Dijitalleşmesi ve Polislik Faaliyetleri}

Bilgi ve iletişim teknolojilerindeki gelişmeler, birey ve toplum yaşamında önemli değişimlerin görülmesinde de etkili olmaktadır. İnternet odaklı dijital mecraların etkinliği, başta akıllı telefonlar olmak üzere, anlık iletişime uygun 
taşınabilir cihazların yaygınlı̆̆, iletişimde dönüşümün habercisi olarak karşımıza çıkmaktadır. Bireylerin toplumsallaşmak, duygu ve düşüncelerini paylaşmak amaciyla yoğun olarak çoklu sanal ortamları tercih ettiği gözlenmektedir. Bu bakımdan günümüzde dijital platformlar, zaman ve mekândan bağımsız olarak içerik üretme ve paylaşımda bulunmaya olanak sağlayan bir iletişim ortamına dönüşmüştür.

Dijital mecralar gerçek yaşamı yansıtmakta, gerçek hayatta işlenen suçların izdüşümleri de sanal ortamlarda görülmektedir. Dijital suçlar bağlamında değerlendirilen bu nitelikli suçlar literatürde siber suçlar olarak adlandırılmaktadır. Siber suçlar, bilişim sistemlerinin güvenliğine ve sanal ortam kullanıcılarına karşı işlenen suçları kapsamaktadır. Bir bilişim sisteminin güvenliğini, buna bağlı verileri ve kullanıcısını hedef alan eylemlerdir (Yayla, 2014, s.152). Verilere zarar verme, ele geçirme, iletişimi engelleme, kayıt etme, banka ve kredi kartlarının kötüye kullanılması en çok rastlanan siber suçlardandır (EGM, 2020). Bu suçlar, Türk Ceza Kanununun doğrudan Bilişim Alanındaki Suçlar başlığı altında tanımladığı, bireylere ve kurumları yönelik gerçekleştirilen suçlardır (TCK, 2004). Bilişim sistemleri kullanılarak haksız menfaat sağlanmasını içermektedir.

Dijital ortamlarda suç potansiyelleri çeşitlendiğinden, hukuki mevzuat güncellenmekte polis etkin mücadelede yetkilendirilmektedir. Kamuoyu tarafından oldukça yakından tanınan ve bireysel önlem alınan gerçek dünyanın suçları, çetin mücadele gerektiren ve sürekli değişen yöntemlerle internet odaklı platformlarda görünmektedir. Genel hukuksal düzenlemelerde bilişim suçları kategorizasyonunda bulunmayan ancak bilişim teknolojilerinden yararlanarak işlenen suç türleri de siber suçlar olarak nitelendirilmektedir. Bir başka değişle elverişli sanal kanallar kullanılarak, suç işlemek ve işlenmesini özendirmek amaciyla gerçekleştirilen eylemler, siber suçlar kapsamında değerlendirilmektedir.

Siber suçların çeşitliliği ve yayılımı dijital evrenin uygun olanaklar sağlaması nedeniyle oldukça hızlı artmaktadır. Hırsızlık, dolandırııılık, yasadışı bahis, çocuk istismarı gibi geleneksel suçlar da çevirim içi olarak işlenmektedir (Küçükvardar, 2018, s.1). Bu türden eylemlerde polis; 5237 sayılı TCK, 5464 sayılı Banka ve Kredi Kartları Kanunu, 7258 sayılı Futbol ve Diğer Spor Müsabakalarında Bahis ve Şans Oyunları Düzenlenmesi Hakkında Kanun ve diğer yetki veren hukuksal dayanaklar doğrultusunda takibat yapmaktadır 
(Altınışık, 2017, s.241; Sönmez, 201, s.50). Bu nedenle siber suçlar, kontrol altına alınması oldukça güç olan, sürekli yeni versiyonları yeşeren, güncel ve karmaşık suçları barındırmaktadır. Anonimlilik ve sahte hesaplar ile iletişim sağlanması, bireylerin yakalanma endişesini azaltırken, suç işlenme oranlarını da yükseltmektedir.

Sanal ortamlar şahıslar gibi organize suç şebekeleri ve terör örgütleri tarafından da suç işlemek amacıyla kullanılmaktadır. Sanal ağlar ile örgüt kullanıcıları ile iletişime geçilmekte ve örgütün etki alanlarını genişletilmektedirler. Kullanıcı profillerinin gizlenmesine ve şifreli haberleşmeye olanak sağladığından, örgütlü suçların faaliyet alanı haline gelmiştir. Bununla birlikte örgüt propagandasının yapılması ve örgüte eleman kazandırılması amacıyla da dijital ortamlar seçilmektedir.

Dijital ortamların önemli bileşenlerinden biri de konusu suç oluşturan kitlesel hareketleri hedefleyen sosyal medya paylaşımlarıdır. Kullanıcıların kendilerine gelen mesajları abartılı ve asılsız iletileri doğru kabul ederek paylaşmasıyla kısa sürede bilinçsiz bir kollektif aklı oluşmaktadır. Bu sosyal medya sosyolojisi gündem olan her konuyu kötüye kullanabilmektedir. Bu içerikteki paylaşımlar, "halk arasında korku ve panik yaratmak amaciyla tehdit ve halkı kin ve düşmanlığa tahrik veya aşağılama" suçları olarak hukuksal mevzuatta yer almaktadır (TCK, 2004, Md. 213 ve Md. 216).

Suçların boyut ve biçim değiştirerek dijital ortama doğru everilmesiyle, polislik uygulamaları ve çalışma metotları da dijital evrene doğru yönelmektedir. Toplumsal kaygı oluşturan paylaşımların analizi, bilişim sistemleri konusunda uzmanlaşmış birimler tarafından gerçekleştirilmektedir. Emniyet Genel Müdürlüğü Siber Suçlarla Mücadele Daire Başkanlığı, siber suçlar ile ilgili yapılan çalışmalarda, tüm illerin genel koordinasyonundan sorumludur (EGM, 2020). Çalışmada öncelikle yer alan İstanbul merkezli tehdit oluşturan ve konusu suç teşkil eden içeriklerin paylaşılmasında, polislik süreçlerini yürüten birim ise İstanbul Emniyet Müdürlüğü, Siber Suçlarla Mücadele Şube Müdürlügüüür.

Polisin siber suçlarla mücadelesinde ilk aşama, çoklu sanal ortamların genel kontrolü esasına dayanmaktadır. Sanal devriye görevi web siteleri, sanal platformlar, bloglar gibi, öncül açık kaynakların incelenmesini kapsamaktadır. Gündemi belirleyen öncellikli ve hassas konularda iletişimsel parametreler analiz edilmektedir. Kitlesel hareketleri teşvik edici paylaşımlar, asılsız içerik ve görüntülerin tespiti yapılmaktadır. İkinci aşamada kamu düzenini 
açık ve yakından tehdit eden paylaşımlar yapanların profilleri ve gerçek kimlikleri belirlenmektedir. Son aşamada ise operasyonel faaliyetlerle dijital ortamlarda suç işleyen şahıslar yakalanarak, adli süreçler başlatılmaktadır.

\section{Covid-19 Bağlamında Misenformasyon, Dezenformasyon Olguları ve Toplumsal Etkileri}

Dünya Sağlık Örgütü tarafından 31 Aralık 2019 tarihinde, Çin'in Vuhan kentinde, daha sonra Covid -19 isimlendirilecek solunum yolu rahatsızlığının ortaya çıktığını bildirilmiştir. 7 Ocak 2019'da Dünya Sağlık Örgütü, hastalığın yeni tip bir koronavirüsten kaynaklandığını açıklamıştır (WHO, 2020; Euronews, 2020). Ortaya çıktığı ilk günlerde bölgesel bir epidemi olarak görülen salgın Asya sınırlarını aşarak, global ölçekte tehdit oluşturan bir pandemiye dönüşmüştür. DSÖ, 11 Mart 2020 tarihli deklarasyonunda koronavirüs salg1nın, Covid-19 olarak isimlendirildiğini, dünyada bu salgın nedeniyle, 114 ülkede 118 000' den fazla vaka ve 4 bin 291 can kaybı yaşandığını duyurmuştur. 11 Mart 2020, Türkiye'de ilk Covid-19 vakasının görüldüğü tarih olarak da kayıtlara geçmiştir (WHO, 2020; T.C Sağlık Bakanlığı, 2020). Bu tarihten itibaren, Sağlık Bakanlığının koordinesinde Covid-19 salgınına karşı tüm şehirlerde, en üst düzeyinde tedbirler alınmıştır.

Salgının başlangıcından itibaren sosyal izolasyon nedeniyle kitle iletişim araçları yoğun bir şekilde kullanılmakta, hastalık hakkındaki gelişmeler kamuoyu tarafından yakından takip edilmektedir. Maske-sosyal mesafe-temizlik üçlüsü, Covid-19 salgını ile mücadelenin vazgeçilemez unsurları olarak görülmektedir. Bu bağlamda konun uzmanları tarafından kullanılan kavramlar, gündelik hayatın sıradan kelimeleri haline gelmektedir. Salgının tespiti amaciyla burun ve boğazdan alınan örnekleme işleminin PCR testi olduğu, Filyasyon teriminin hastalığın kaynağını bulmak ve yayılım zincirini takip etmek amaciyla yapıldığı, koronavirüsün bulaştığı ancak hiçbir hastalık belirtisi göstermeyen kişilerin Asemptomatik hasta olarak adlandırıldığı, toplumun büyük bir kesimi tarafından bilinmektedir (BBC, 2020). Covid-19 salgınına yönelik güncel gelişmeler, yayılım süreci, tehditleri ve korunma yöntemlerine ilişkin açıklamalar ilgiyle izlenmektedir.

Hastalık hakkında farkındalık oluşturulması amacıyla yapılan uzun süreli yayınlar, uzmanların görece yorumları, hastalığın süresi ve tahribatı hakkındaki belirsizlik sosyo-psikolojik sorunlara neden olmaktadır. Salgında güncel 
verilerin algılanışı ve hastalığa karşı hissedilen endişe oranı, bu sorunlarla mücadele bireysel farklılıkları ortaya çıkarmaktadır (Asmundson ve Taylor, 2020). Felaketleştirilen senaryolar, aşırı hastalık bulaşma takıntısıyla ortaya çıkan anksiyete bozukluğu, koronafobi olarak literatüre kazandırılmıştır. Yaşanan yoğun stres; çarpıntı, sık nefes alma, terleme gibi bedensel tepkilerin verilmesine ve yaşam kalitesinin bozulmasına yol açabilmektedir (Aksakallı, 2020; Yeşilay, 2020). Gösterilen reaksiyonlar bireylerin aile ve sosyal çevresini de etkilemektedir.

Dünya Sağlık Örgütü'nün ve Sağlık Bakanlığı'nın etkin çalışmaları doğrultusunda, halk sağlığının korunması ve salgından en az hasarla kurtulabilmek için çeşitli önlemler alınmaktadır (Acar, 2020, s.15). Hastalığın yaygınlığını azaltmak amacıyla zorunlu olmadıkça ikametlerden çıkılmaması, toplum hayatında yeni normal olarak adlandırılan ekonomik, sosyal ve eğitimsel değişikliklere sebep olmaktadır. Birçok meslek grubunun rutin işlemleri ve tüm kategrasyondaki eğitim faaliyetleri, dijital mecralar aracılı̆̆ıyla uzaktan yapılması zorunlu hale gelmektedir. Kisıtlanan sosyal aktivite alanları ve hastalığın karşı oluşan tedirginlik ve bilinmezlikle dijital medya kullanımını arttırmaktadır. Salgın hakkında hızlı ve daha tutarlı bilgi edinme ihtiyacı, bireyleri sosyal medya platformlarında paylaşılan bilgilere maruz bırakmaktadır (Aksakallı, 2020). Merak ve kaygı duygularının karmaşıklığıyla, doğru ve yanlış bilginin ayırt edilmesi zorlaşmakta ve bilginin sanal ortamlarda paylaŞım hızı da artmaktadır.

Covid-19 salgınına yönelik yeni olanaklar, sınırlılıklar ve tedavi yöntemleri dijital medyada kullanıcıları tarafından ilgiyle takip edilmektedir. Hastalık bulaşmasının engellenmesi amacıyla fiziksel mesafesini korunmaya çalışıldığı bu süreçte, sosyal medya mecraları psikolojik sağlığın korunması, hızlı ve kapsamlı sosyal bir ilişki kurulmasında kurtarıcı olarak görülmektedir. Sanal ağlardaki uygulamalar çeşitlenmekte, çok amaçlı kullanıma uygun olarak fonksiyonları ve kaliteleri artmaktadır. Özellikle görüntülü haberleşme yöntemlerindeki gelişmeler, yakınlarını merak eden ve özleyenler tarafından memnuniyetle karşılanmakta ve uygulamalar oldukça yoğun bir şekilde kullanılmaktadır. Diğer bir ifadeyle, koronavirüs kapsamında tedbirler, gerçek dünyayı ve gündelik hayat aktivitelerini sanal ortama taşımaktadır (Vural ve Bat 2010, s.3349). Ancak bilimsel verilerle dijital dedikoduların, resmi açıklamalar ile uydurma haberlerin bir arada olduğu bu ortamlar, zihinsel karışıklığa ve sürekli hissedilen bir endişe halinin varlığına sebep olmaktadır. Aslı 
değiştirilmiş görüntü ve ses dosyaları, söylentiler, uydurma sağlık bilgileri, yanıltıc tıbbi tavsiyeler Covid-19 ile mücadeleyi daha da zorlaştırmaktadır. Toplumu meşgul eden gereksiz iletiler, zor şartlar alında görev yapan ve gündemi yoğun olan uzmanların, aynı zamanda sağlıksız bilgileri düzelmek için de çaba göstermelerine sebep olmaktadır.

Virüsle mücadelede; yüksek dozda c vitamini kullanımı, sıcak su içilmesi, boğazın sürekli ıslak tutulması, antibiyotik kullanımı bol sirke ve bitkisel çay tüketimi gibi bilimselliği kanıtlanmamış paylaşımlar yayılmaktadır. Bunun yanında insan sağlığı açısından tehlike oluşturan, çamaşır suyu ve saf alkol gibi etken maddelerin de tavsiye edilmesi, sosyal ağlarda yaşanan paranoyanın boyutların ortaya koymaktadır (Bernard, 2020; Kalsın 2020). Dezenformatik paylaşımlar geri dönülmez sonuçları da beraberinde getirmektedir. İstanbul'da koronavirüsten korunmak amaciyla saf alkol içen Türkmenistan vatandaşlarının, 20'sinin ölümüne ve 34'ünün de ciddi tedavi görmelerine kadar uzanan bir etkilenme süreci yaşanmaktadır (Somer \& Öztürk, 2020). Sosyal ağlar komplo teorilerinin yayılmasında da önemli bir role sahiptir. Sağlık kurumlarından geldiği iddia edilen, şehirlerin karantinaya alınacağı yönündeki misenformatik paylaşımlarla, $5 \mathrm{G}$ teknolojisini koronavirüs salgınının önemli sebeplerinden biri olarak gösteren dezenformasyonlar, İngiltere'de baz istasyonlarının yakılmasına neden olmuştur.

Dünya Sağlık Örgütü ve çeşitli yetkili kurumların resmi uyarılarına rağmen, koronavirüse ilişkin dijital mecralardaki yanlış yönlendirmeler ve abartılı tutumlar, kişilerarası iletişimde ötekileştirme eğilimlerine ve kaos oluşturan davranışların meydana gelmesinde önemli bir paya sahiptir. ABD'de Asya kökenli Amerikalılara, koronavirüsü bulaştırdıkları gerekçesiyle gerçekleştirilen ırkçı saldırılar gündem oluşturmaktadır. Indiana'da iki otelin Asyalı misafirlerin konaklamasına izin vermemesi gibi olaylar meydana gelmektedir. Ukrayna'da da salgın nedeniyle Çin'den tahliye edilen vatandaşları taşıyan otobüsler taşlanmıştır (O'Connell, 2020). Terör örgütleri ve organize suç şebekeleri tarafından anonim ve yetkililer adına açılmış sahte hesaplardan yapılan provakatif paylaşımlarla, salgınla mücadele yöntemleri istismar edilmektedir. Hindistan'da koronavirüs tespiti yapmaya çalışan doktorlar, dezenformasyon içerikli paylaşımların etkisiyle taşlı saldırıya maruz kalmiştır (Kara, 2020). Londra' da Covd-19 kapsamındaki yasağa ve halk sağlığı açısından risk oluşturmasına rağmen sosyal medyadan örgütlenerek sokak 
partisi düzenleyen grup, güvenlik güçlerine mukavemet göstermiş, 15 polis yaralanmış ve araçlarına zarar verilmiştir. (Esen, 2020)

Sosyal medya platformlarında gerçekleştirilen misenformasyon ve dezenformasyon içerikli paylaşımlar, günümüzde dijital topluma dönüşen kamuoyunu çok boyutlu olarak tehdit etmektedir (Bradshaw \& Howard 2018 p. 28). Kaotik ve karmaşık doğası bulunan çoklu sanal ortamlar, toplumun dikkatle ve hassasiyetle değerlendirmesi gereken bir yapıya doğru evrilmektedir. Bu bakımdan asılsız ve yanıltıc bilgilerin yayılmasında üretenler kadar, paylaşanların da kaçınılmaz olarak sorumluluğu bulunmaktadır. Dünya Sağlık Örgütü viral olarak yayılan bu yeni tip salgin türünü, infodemi olarak adlandırmaktadır (Aydın, 2020, s.88). Örgüt, infodemiyi; “bilgi kirliliği oluşturarak; toplumları bundan olumsuz etkilemek, toplumların psikolojisini bozmak, toplumsal kaos, korku ve panik oluşturmak, toplumsal bağışıklığı, direnci, güveni veya tepkileri ortadan kaldırarak; insanların, toplumların veya ulusların ruh ve beden sağlığını bozmayı amaçlayan bir salgın türü" olarak ifade etmektedir (Ünal ve Kılınç 2020, s.8). Bu salgın, Covid-19 ile olan mücadeleyi olumsuz etkilemektedir. Uluslararası ve ulusal kurumlardan ve toplum bu konuda duyarlılık göstermesi beklenmektedir.

İnfodemik paylaşımlarla mücadele edilmesi amacıyla, tüm dünya genelinde bilgiyi teyit eden internet siteleri oluşturulmaktadır. Bu web siteleri dijital medyada gündemi meşgul eden bilgilerin, doğru olup olmadığını araştırmakta ve çoklu sanal ortam kullanıcılarına doğru bilgiyi ulaştırmaktadır (Kiraz, 2020, s.11). Ancak koronavirüs salgını hakkında dijital platformlarda paylaşılan bilgilerin, doğruluğunu teyit eden ya da yanlışlı̆̆ını ortaya koyan resmi formatta bir mekanizmaya henüz rastlanmamaktadır. Ayrıca dezenformasyon ve misenformasyon içerikli paylaşımlara, gecikmeksizin müdahale eden ya da yayılımını durduran kurumsal bir inceleme merkezi oluşturulmamıştır. Bu konudaki çalışmalar bireylerin tekil çabaları ile sürdürülmektedir. Dijital medyada gerçekleşen Covid-19 hakkındaki asılsız bilgi düzeltme çabaları, Sağlık Bakanlığı tarafından oluşturulan Bilim Kurulu Üyeleri ve tanınan uzman akademisyenlerin geleneksel ve sosyal medya programlarında verdikleri bilgilerden oluşmaktadır. 


\title{
Amaç ve Yöntem
}

\begin{abstract}
Amaç
Çalışmanın amacı suça dönüşen misenformasyon ve dezenformasyonun üretim motivasyonuna yönelik detayların ortaya konması ve bu noktadan hareketle polislik perspektifinden çözüm önerilerinin üretilmesi oluşturmaktadır. Bu bağlamda üç araştırma sorusuna cevap aranmaktadır:

1. Covid-19 sürecinde suça dönüşen misenformasyon veya dezenformasyonun içeriği nedir?

2. Covid-19 sürecinde üretilen misenformasyon ve dezenformasyonun üretim motivasyonu nedir?

3. Suç olarak misenformasyon ve dezenformasyonun önlenmesi noktasında dijital polisliğin katkısı nedir?
\end{abstract}

\section{Yöntem}

Çalışma kapsamında suça dönüşen misenformasyon ve dezenformasyonun içeriği, üretim motivasyonu ve önlenmesine yönelik dijital polisliğin katkısı ortaya konmak istenmektedir. Kalitatif ve gözleme dayalı veriler elde edilen bu betimsel alan araştırması, Covid-19 vakasının tespit edildiği ilk gün ile yeni normalin başladığı ilk gün arasındaki tarihleri kapsamaktadır. Çalışma çerçevesinde, İstanbul Emniyet Müdürlüğü, Siber Suçlarla Mücadele Şube Müdürlüğünde görev yapan uzmanlar Iriste ve Katane (2018, s.77, 78) tarafından ortaya konmuş olan uzman seçim prensiplerine göre belirlenmiştir. Bu bağlamda öncül deneyimleri, eğitim seviyeleri ve aktif görevleri göz önünde bulundurularak, Tablo 1'de belirtildiği gibi çalışmanın veri toplama aşamasını gerçekleştirmek amaciyla 8 uzmanla görüşülmüştür. Gerçekleştirilen odak grup tartışması not tutularak kayıt altına alınmış ve tartışma yaklaşık 7 saat sürmüştür. Görüşlerine başvurulan uzmanlar, amaca yönelik örneklem seçme perspektifi benimsenerek belirlenmiştir. Ayrıca seçilen uzmanların misenformasyon ve dezenformasyon vakalarına yönelik bilgi birikimlerinin ve tecrübelerinin bulunması, temel bir kriter olarak belirlenmiştir. Odak grup görüşmeleri gerçekleştirilirken Nyumba ve arkadaşlarının (2018) ortaya koymuş olduğu, odak grup tartışması tasarım ve uygulama adımları ile Iriste ve Katane (2018) tarafından uzman görüşmelerinin gerçekleştirilme biçimi bağlamında ortaya konmuş olan, komisyon yaklaşımı benimsenmiştir. 
Polislik Perspektifinden Dijital Misenformasyon ve Dezenformasyon: Covid-19 Örnek Olay1 Bağlamında Bir Analiz

Tablo 1. Uzmanlarn Öncül Meslek Deneyimleri, Eğitim Dereceleri ve Aktif Görevlerine Göre Tasnifi

\begin{tabular}{|c|c|c|c|}
\hline \multicolumn{4}{|c|}{ Uzman Kualifikasyonları } \\
\hline Uzmanlar & Öncül Meslek & Eğitim & Aktif \\
\hline & Deneyimleri & Derecesi & Görevi \\
\hline Uzman 1 & Güvenlik Şb. Md. & Yüksek Lisans & Yönetici \\
\hline Uzman 2 & Asayiş Şb. Md. & Yüksek Lisans & Yönetici \\
\hline Uzman 3 & Polis Merkezi Amirliği & Yüksek lisans & Yönetici \\
\hline Uzman 4 & Bilgi İşlem Şb. Md. & Yüksek Lisans & Yönetici \\
\hline Uzman 5 & Bilgi İşlem Şb. Md. & Yüksek Lisans & Görevli \\
\hline Uzman 6 & Bilgi İşlem Şb. Md. & Lisans & Görevli \\
\hline Uzman 7 & Güvenlik Şb. Md. & Yüksek Lisans & Görevli \\
\hline Uzman 8 & Asayiş Şb. Md & Lisans & Görevli \\
\hline
\end{tabular}

Çalışma grubu belirlendikten sonra, her bir amaç sorusunun cevabını almak üzere alt görüşme soruları oluşturulmuştur. Çalışma kapsamında, 11 Mart - 1 Haziran 2020 tarihleri arasında Covid-19 ile ilgili olarak suça dönüşmüş misenformasyon ve dezenformasyon vakaları, uzmanlarla tartışılarak ele alınmıştır. Çalışma, polis operasyonları neticesinde ulaşılan İstanbul merkezli vakalar ile sınırlandırılmıştır. Böylece kalitatif ve gözleme dayalı veriler elde edilmiştir. Araştırmanın verileri analiz edilirken bir iç güvenirlik parametresi olarak öncül literatürden faydalanılmış, veriler kaydedilmiş, teorik olarak yapılandırılmış bir veri toplama ve analiz süreci uygulanmıştır (Tablo 2). Dış güvenirlik noktasında ise; farklı uzman görüşlerinden doğrudan alıntılar yapmak, aktarılan vakalar hakkında bilgi vermek ve tekrar uygulanabilirliği ortaya koymak amacıyla, araştırma sürecinin adımları hakkında bilgi verilmesi hususu göz önünde bulundurulmuştur.

Tablo 2. Araştırma Tekniği Açısından Uzmanlık Aşamalan

\begin{tabular}{lll}
\hline Uzmanlık Hazırlık Aşaması & Uzmanlık Prosedürü & \\
\hline $\begin{array}{l}\text { Uzmanlığın Detaylı } \\
\text { Planlanması }\end{array}$ & Uzmanlarla Doğrudan/Aracılı İletişim & $\begin{array}{l}\text { Veri İşleme ve } \\
\text { Uzmanlık Analizi }\end{array}$ \\
\hline Uzmanların Seçimi & Veri Toplama \\
& Olan / Olmayan Süreç & Veri İşleme \\
\hline Uzmanlar için Materyal & Uzmanların Nitel/Nicel Olarak Görüş ve & Elde Edilen \\
Tasarımı & Değerlendirmeleri & Sonuçların Analizi ve \\
& & Değerlendirilmesi \\
\hline
\end{tabular}

Kaynak: Iriste ve Katane, Eğitimde Araştırma Yöntemi Olarak Uzmanlık 


\section{Bulgular}

Araştırmanın ilk amaç sorusu hakkındaki uzmanların görüşleri; Covid-19 sürecinde misenformasyon ve dezenformasyon içerikli paylaşımların, suça dönüştüğü noktanın belirlenmesine ve toplum güvenliği bağlamında etkilerinin ortaya konulmasına yönelik çıkarımlar elde edilmesine olanak sağlamaktadır.11 Mart-1 Haziran 2020 tarihleri arasında İstanbul Emniyet Müdürlüğü, Siber Suçlarla Mücadele Şube Müdürlüğü tarafından bizzat tahkikatı sürdürülen, misenformasyon ve dezenformasyon içerikli suç oluşturan 28 hesap ve diğer emniyet birimleri tarafından işlemleri gerçekleştirilmek üzere tespitleri yapılan Twitter paylaşımı değerlendirilmektedir. Kriminalize olmuş bu iletiler, yoğun olarak kullanılan sosyal medya platformu Twitter'da, kitlesel tesiri paylaştıkça artan başlatıcı bir fonksiyon üstlenmektedirler. Suç kapsamında değerlendirilen misenformasyon ve dezenformasyon paylaşımlarının, takipçi sayısına bağlı olarak yayıldığı dikkate alındığında; örgütlenme boyutlarının önemli ölçüde genişlediği, sanal aktörlerin hakimiyetlerinin ve kitlesel tutumları manipüle etme güçlerinin katlanarak büyüdüğü görülmektedir.

Türkiye'de Covid-19 salgınının ortaya çıtığı Mart ayında, daha çok vaka ve ölüm sayılarına yönelik paylaşımların yapıldığı görülmektedir. Bu dönemde salgının tehlike boyutu ve yayılım hızı hakkında bilgiye ulaşma çabaları, sosyal medyada yüksek etkileşim sağlanmasına neden olmaktadır. Çalışmada ele alınan bu etkileşim sirkülasyonu, genel itibariyle resmi açılamaların aksine, bulaşma ve ölüm sayısının fazla olduğuna yönelik bağlamdan kaydırma içerikli paylaşımlardan oluşmaktadır. Uzmanlar, sokağa çıkma kısttlamalarının başladığı Nisan ayından itibaren, ekonomik sebepler öne sürülerek kitlesel hareketleri teşvik eden paylaşımlara rastlandığını belirtmektedir.

- “.. pozitif çıkmıs ama ne hikmetse haber yok bir şey yok insanlardan gizliyorlar. Sayı fazla doğrusunu söylemiyorlar."

Ayrıca odak grup görüşmelerinde uzmanlar, Twitter üzerinden açlan "ödemiyoruz hareketi" isimli hesap ve bağlantılı hesaplarda; elektrik, su, doğalgaz, telefon, kredi kartı vb.gibi faturaların vatandaşlarca ödenmemesini teşvik edici misenformasyon ve dezenformasyon paylaşımlarını tespit ettiklerini ifade etmektedirler (Odemiyoruz, 2020). Bunun gibi "Biz Bize Yeteriz" kampanyasına katılım sağlanmaması ve destek verilmemesi amacıyla benzer 
isimlerle açlan Twitter hesaplarında, propaganda amaçlı paylaşımlar uzmanlar tarafından belirlenmiştir (DHA, 2020). Kitleleri provoke eden, devlet büyükleri aleyhine propaganda yapan ve kurumları itibarsızlaştırmayı hedefleyen, bu türden hesap ve paylaşımlarla ilgili soruşturmalar yürütülmektedir.

- ... “\#ÖdemeYapmiyoruz bence de yapmayalım gelir yok gider çok devlet yok hirsız çok."

- "Millete sesleniş abi devlete bă̆ış yapmayın, ...'e yapın en azından paranız güvenle ihtiyaç sahibine ulaşacağın bilirsiniz. Bunlar parayı derneklerle aklar 2 kamyon gıda yardımı yapar bitirir bi dünya da şov yaparlar."

Soruşturmalar "halk arasında korus ve panik oluşturulması ile halkın kin ve düşmanlığa tahrik edilmesi" suçlamasıyla TCK'nın 213. ve 216. maddeleri kapsamında yapılmaktadır. Misenformsyon ve dezenformasyon içerikli paylaşımların suç karinesi içerisinde değerlendirilmesindeki temel parametre, yasaların suç saydığı bir fiilin bireysel veya topluca sanal platformlarda gerçekleştirilmiş olmasıdır. Diğer bir karine de işlenen suçtan zarar görenlerin bulunması halidir. Soya medya platformlarında misenformasyon ve dezenformasyon içerikli paylaşımlar, her iki karineyi ihlal ederek, bireysel sıkıntılara ve toplumsal infiale neden olduklarında hukuksal düzenlemeler doğrultusunda incelenmektedir.

Dijital misenformayon ve dezenformasyon içerikli paylaşımların, toplumsal etkileri çok hızlı görülmektedir. Farklı hesaplarla organize edilen sistemli meydan okuma, kullanıcıları bilinçli ya da bilinçsiz olarak, sanal ortamın kitlesel hareketliliğine ve kanunsuz eylemlerine ortak etmektedir. Dezenformasyon içerikli ilk paylaşımlar, maksatlı yanlışlığı ve tahrifatı anlaşılıncaya kadar kullanıcılar tarafından doğru kabul edilmektedir. Uzmanlar, suçun meydana gelmesinde ve kitlesel hareketliliğin oluşturulmasında, bu paylaşımların önemli rolü olduğu görüşündedir.

- “Bu akşam 11.30'da kimse sokakta olmamal. Kapılar ve pencereler kapalı kalmahıdır...Korona virüsünü yok etmek için havadaki 5 helikopter sprey dezenfektanı. Lufton bu bilgileri tüm kişilerinize yaymlaym. Şeklinde mesaj geliyor."

Dezenformatik paylaşımların iki zararlı boyutu görülmektedir. İlki dezenformasyonların kendi iç dinamiklerinden kaynaklanan olumsuz etkileri, ikin- 
cisi ise paylaşımların yanlışlığını ifşa eden bilgilerin gölgelenmesi ve görünürlüğünün azaltılmasıdır. Doğru kabul edilen misenformatik bilgilerin sosyal gruplarda dağılmasıyla, toplumun yaşam biçimleri etkilenmekte, gerçek kurum ve uzman açıklamalarının inanılırlığı ve güvenirliği zedelenmektedir.

- Korona virüsü gizleniyor arkadaşlar bizim bir akrabamıza da dün teşhis konuldu."

- "İstanbul ... korona virüsten dolayı öldüğü söyleniyor. (Yerde yatan bir kişinin görüntüsü)"

Covid-19 tedbirlerinin yetersiz ve vefat sayısının bildirilenden çok fazla olduğu, hastalarla gereken şekilde ilgilenilmediği ve yaşlılara yönelik hakarete varan paylaşımlara dikkat çekmektedir. Hastalığın yayılımının engellenmesinde gereken özenin gösterilmediğinden bahisle, toplumsal dinamikleri hareketlendirici ve ayrıştırıcı paylaşımlar görülmektedir. Uzmanlar, bu içerikteki iletilerin kitlesel tutumları etkilediği görüşünde hemfikirdir.

- Bizde yeni başladı açıklamalar ama maalesef söylenenden çok çok kötüyüz. Ölümler söylenenden kat ve kat daha fazla."

- "Bırakın yaşlılar çıkıp ölsün ya hem toplu taşımada yer vermeyiz."

- "Allah rahmet eylesin demekten başka çare yok devir gençlerin devri iyi oldu bu virüs ölsün tüm yaşlilar".

- "Umreden dönen cami imam, karantinadan kaçıp camide namaz kıldırmış, yemekli mevlit düzenlemiş, tüm çarşıyı gezip helallik dilemiş să̆olsun."

Araştırmanın ikinci amaç sorusunda uzmanlar; misenformasyon ve dezenformasyon içerikli paylaşımların üretim motivasyonunu, suç kapsamında değerlendirdikleri vakalar ve bunlara dair içerikler doğrultusunda yorumlamaktadır. Genel olarak polisin görevini yerine getirirken karşılaştığı suçlara yönelik müdahaleleri, yardım ve şikâyet konularında gerçekleştirdiği vazifeleri, sağlık ve itfaiye ekiplerinin olay yerlerine giriş görüntüleri paylaşılmaktadır. Covid-19 vaka veya ölüm sayılarının artışını konu edinen misenformasyon ve dezenformasyon içerikli paylaşımlara yoğunlaşılmaktadır. Bunun temel nedeni Covid- 19 görülmeyen yerlerde dahi yaygın olarak hastalığın olduğunu abartarak paylaşan hesaplara rastlanılmasıdır.

- "Test kitleri yetersiz. Hastalarm bireyden haberi yok. Ölü sayısın gizliyorlar. Ne karantina hazırlandı ne önlem alındı. Sen ayakta uyu otel parası ver." 
Yurtdışında herhangi bir yerde görülen vakalar, İstanbul'un belirli semtlerini işaret ederek paylaşılmaktadır. Resmi açıklamaları yalanlayıcı ölüm ve vaka sayıları, yeri bilinmeyen ve yanıltıcı paylaşımı kuvvetlendiren; mezarlık, gasilhane ve hastane görüntüleri ile birlikte yayılmaktadır. Normal ölüm ve hastalıkları, Covid-19 salgını nedeniyle gerçekleşmiş gibi gösteren hesaplarla da karşılaşılmaktadır. Bununla birlikte salgının yoğun olarak yaşandığı dönemde sağlık ve güvenlik ekiplerinin, doğal hayatın akışı içerisinde gerçekleştirdikleri görev ve müdahalelerini, Covid-19 salgını ile ilişkilendiren paylaşımlar dikkat çekmektedir. Bu tür misenformasyon ve dezenformasyon içerikli paylaşımlar, hızlıca yayıldığından ve telafisi güç zararlar meydana getirdiğinden, uzmanlar tarafından öncelikli olarak değerlendirilmektedir. Bu süreçte savcılık makamının talimatlarıyla, kanunların verdiği yetkiler doğrultusunda, resen ve şikâyet neticesi takibatı yapılan bu paylaşımlarla, Covid-19 salgının Türkiye genelinde yoğun olarak görüldüğü ve cevap verilebilirlik oranın düşük olduğu izlenimi verilmektedir.

Uzmanlar, kitlelerin tutumlarının belirlenmesinde ve kollektif bilincin oluşmasında Twitter'ı en etkili sosyal medya platformu olarak görmektedir. Kullanıcı hesabının fazlalığı ve popülerliği nedeniyle, diğer sosyal medya platformlarında paylaşılan bilgiler genelde Twitter 'da da bulunmaktadır. Çoklu sanal ortamlarda birçok iletişimsel platform olmakla birlikte, siber suçlarla mücadelede kategorik olarak Twitter önde gelmektedir. Çalışmada yer alan uzmanların deneyimleri ve elde ettikleri verilere göre, suç odaklı paylaşımlarda; ikinci sırada YouTube, üçüncü sırada Facebook ve dördüncü sırada Instagram gelmektedir. Kullanıcı profilleri de kullanılan platformların özelikleri ve olanakları doğrultusunda değişmektedir. Ancak polisin siber suçluları tespitinde tüm sosyal medya platformlarında görülen anonimlilik olgusudur. Suça dönüşen misenformasyon ve dezenformasyon paylaşımlarını, anonimlilik esaslara göre gerçekleştiren kullanıcılar, profillerine ulaşmak için polisin çaba göstermesi gerektiğini oldukça iyi bilmektedirler. Bu zafiyeti nedeniyle dijital medya, mevcut durumda yoğun yakalanma korkusu yaşanmadan suç işlenebilen bir mecra olarak görülmektedir. Bu ortamlarda suç işleyen hesap kullanıcılarına ulaşmak ve gerçek profillerini belirlemek amacryla operasyonel faaliyetler icra edilmektedir.

Araştırmanın üçüncü sorusu, dijital polisliğin temel bileşenleri olan gözlem ve takip unsurlarına odaklanmaktadır. Uzmanlar, dijital misenformasyon ve dezenformasyon üretiminde ve dolaşıma sunumunda, kullanıcıları 
motive eden gücü gözlemleriyle tespit etmeye çalışmaktadırlar. Uzmanlara göre Covid-19 paylaşımlarının temel motivasyon unsurunu, birey ve toplum sağlığı hakkında duyulan kaygılar oluşturmaktadır. Ekonomik ve politik misenformasyon ve dezenformasyonlar, bir sonraki aşamada görülmektedir. Salgin nedeniyle durdurulan ya da biçim değiştirerek sürdürülen; örf, adet ve gelenekler hakkındaki paylaşımlar ise, toplumsal duyarlılık göstermeyenleri hedef alan içeriklerden oluşmaktadır. Bununla birlikte Covid-19 ile ilgili oldukça fazla hashtag açıldığı, gerçek dünya kavga ve kutuplaşmalarının, dijital medya arenasına taşındığı gözlenmektedir. Uzmanlar bu durumun, misenformatik ve dezenformatik paylaşımları, niteliksel ve niceliksel olarak arttırdığını vurgulamaktadır. Ayrıca Covid-19 salgının oluşturduğu psikolojik rahatsızlık ve karşı koyamadıkları dijital ortamlarda var olma dürtüsü, kullanıcıları suç oluşturan içeriklerin üreteni ya da paylaşanı haline getirmektedir.

- "... Fakültesi'nde dezenfektan diye koydukları şey çamaşır suyu çıktı ve kullandiktan sonra elimin son durumu bu. Okulun bu saçmalıkla ilgili bir açıklaması var mi? Öğrenciler ellerini bunu kullandıktan sonra yüzüne götürse açıklamasimı kim yapacak?\#coronatuerkiye"

Uzmanlar misenformasyon ve dezenformasyon yayılımının önlenmesi ve dolaşımda olanlar hakkında gerekli yasal işlem yapılması amacıyla gerçekleştirilen dijital polislik faaliyetlerinde, takip mekanizmasının önemli olduğuna işaret etmektedir. Çoklu sanal ortamlarda gerçekleştirilen proaktif ve reaktif görevler sanal devriye olarak nitelendirilmektedir. Uzmanlar sanal devriyeyi, gerçek hayattaki polis devriyesinin dijital ortamdaki izdüşümü olarak görmekte ve önceki görevlerindeki deneyimlerinden, siber suçların takibinde de yararlandıklarını belirtmektedirler. Covid-19 sürecinde sanal devriye faaliyetleri, toplum sağlığı ve güvenliği açısından istismar edilen konulara yoğunlaşmaktadır. Usulüne uygun olmadan üretilen ve satılan maske, kolonya, dezenfektan, Covid -19 test kiti, ilaç gibi paylaşımlar öncelikli olarak incelenerek gerekli yasal işlemler yapılmaktadır. Provakatif ve algı yönetimi amaçlı paylaşımlar ile çeşitli dolandırıcılık versiyonlarını içeren iletiler hakkında hukuksal takibatlar sürdürülmektedir. Bu bağlamda kurumların resmi sitelerinin phishing yöntemiyle suiistimalinin önlenmesi ve suça dönüşen 
spekülatif iletilerin hızlı yayılımının engellenmesi amacıyla, sanal devriye faaliyetleri gerçekleştirilmektedir.

\section{Tartışma ve Sonuç}

Çalışmada İstanbul merkezli polis operasyonlarıyla, Covid-19 salgını bağlamında deşifre edilen suç içerikli paylaşımlar, İstanbul Emniyet Müdürlüğüu, Siber Suçlarla Mücadele Şube Müdürlüğü uzmanlarının görüşleri doğrultusunda analiz edilmektedir. Covid-19 sürecinde suç oluşturan misenformatik ve dezenformatik iletilerin yoğun olarak görülmesinin temelinde, dijital ortamların kontrolsüz ve denetimsiz yapısı belirleyici olmaktadır. Profil ve hesaplar şahısların bilgisi dışında kişisel bilgileri veya fotoğrafları kullanılarak başkaları tarafından sahte olarak oluşturulabilmektedir. Diğer taraftan profil ve hesaplar başkaları tarafından hacklenmekte ve şahısların rızası dışında kullanılabilmektedir. Ayrıca şahıslar aynı isim ya da rumuz ile birden fazla hesap açlabilmektedir.

Dikkat çeken önemli bir husus da dijital ortamlarda kullanıcıların paylaŞımlar üzerinde ekleme, çıkarma ve değiştirme yetkisine sahip olmalarıdır. Bu karmaşık hesap erişim yetkileri ve açıları dezenformasyonu suça dönüştürebilmekte, suç paylaşımcılarının tespitini güçleştirmektedir. Suç içerikli dezenformasyon paylaşıldıkça, yeni suç ortakları bulmakta ya da misenformasyonlarla kabuk değiştirerek yanlış bilginin etki alanı ve şiddeti arttırılmaktadır. Covid-19 salgının görüldüğü ilk evrede kullanıcıların panik ve merak duyguları ile ya da kasıtlı olarak, suç içerikli misenformasyon ve dezenformasyon paylaşımlarında bulundukları görülmektedir. Global bir travmanın yaşandığı koronavirüs sürecinde polis tarafından kamuoyunda korku oluşturma ve halkı kin ve düşmanlığa tahrik suçlarından hukuksal işlemler yapılmaktadır. Ancak sanal platformlarda üzerinde durulması gereken başka bir olgu da nefret söylemidir. Araştırma örneklemlerinde belirtildiği gibi, Covid-19 salgını önlemleri bahane edilerek, yaşlı vatandaşları yeren ve hatta ölmesini isteyen paylaşımlar dahi görülmektedir. Bu misenformasyon ve dezenformasyon suçlarının, TCK'nın 122. maddesinde yer alan nefret ve ayrımclık suçu kapsamında ele alınmasının uygun olacağı değerlendirilmektedir (TCK, 2004).

Uzman görüşleri ile tespit edilen misenformasyon ve dezenformasyon suçları birlikte değerlendirildiğinde, kullanıcıların Covid-19 sürecinde sosyal 
ağlarda fazla vakit geçirdikleri, psikolojik sarsıntı nedeniyle, özensiz ve dikkatsiz paylaşımlarda bulundukları anlaşılmaktadır. Bu anksiyete durumu, Dehşet Yönetimi Kuramcllarına göre varoluşsal kaygıların, birey tutum ve davranışlarını kritik seviyelerde etkilemesinden kaynaklanmaktadır (Greenberg, Pyszczynski ve Solomon, 1986; Solomon, Greenberg ve Pyszczynski, 2004). Ölüm korkusu, salgının bulaşma riski dehşet süreçlerinin yaşanmasına neden olmaktadır (Doğulu ve Uğurlu, 2015, s.42). Covid-19'dan korunma güdüsü ve salgın hastalıkla mücadele güçlüğü, dijital ortamlarda bilinçli yada bilinçsiz olarak kullanıcıların, misenformasyon ve dezenformasyon suçlarına iştirak etmelerine sebep olmaktadır.

Doğal hayat koşullarının koronavirüs salgını kapsamında kısıtlanması, krizi karşılama eşiğinin düşüklüğü ve gelişen teknoloji ile kaybolan zaman kavramı, bireylerin dijital medyada var oluş biçimlerini değiştirmiştir. Otoritelerin Yeni Normal olarak adlandırdığı bu zorlu süreçte, toplumsal büzüşme ile yalnızlaşan bireylerin dijital ağlarda bulunma süresi artmıştır (Kuss ve Griffiths, 2011, s.3534; Güleryüz, Esentaş, Yıldız, Güzel, 2020, s.33). Sosyopsikolojik çöküntülere işaret eden paylaşımların çoğalmasının yanı sıra, dijital medyada öne çıkma dürtüsünün de kuvvetlendiği görülmektedir. Sosyal ağlarda olayım da nasıl olursam olayım, kendimi unutturmayayım ya da herkes bir şey yazıyor ben de yazayım düşüncesiyle yapılan paylaşımlar, misenformasyon ve dezenformasyon suçları olarak karşılık bulmaktadır.

Polisin sanal devriye ile deşifre ettiği diğer dijital medya suçu da kitlesel hareketleri hedefleyen misenformasyon ve dezenformasyonlardır. Anonim hesap ve profillerden ya da çeşitli dijital ortam açıklarından yararlanan klavye kahramanları, örgütlü olarak kısa zamanda yüksek paylaşıma ulaşarak, kitlesel eylem ve provokasyon hedeflemektedirler (Bağcı, 2016, s. 1033). Erişilmez olma duygusuyla gerçekleştirilen ve dijital dünyada arka plan örgütlenmesi olarak görülen bu maksatlı paylaşımlar manipüle edilmiş bilgilerden ve meydan okumalardan oluşmaktadır. Ancak uzmanlar suç emareleri açıkça görülen iletileri yayan kullanıcıların, tahkikat aşamasında durumun ciddiyetini ve hukuksal boyutlarını anladıklarında pişmanlık duyduklarını gözlemlemektedir. Suç oluşturan misenformasyon ve dezenformasyon paylaşımlarının üreteni ve dağıtanları, suç saiki ile hareket etmediklerini hatta suç olduğunu bilmediklerini belirtmektedirler. Örneklemler üzerinden yapılan odak grup görüşmeleri, dijital ortamların bireysel ve kitlesel suçların 
işlenmesine, çeşitlenmesine ve suçluların gizlenmesine olanak tanıdığını ortaya koymaktadır. Bu bağlamda doğal hayatı formatlayan yeni normal tedbirlerinin, dijital mecraların suiistimalini engelleyecek şekilde hukuksal düzenlemeler yapılarak genişletilmesi, denetimsizliğin ve kontrolsüzlüğün giderilmesi gerekmektedir.

Pandemi ile birlikte dijitalleşmenin hızlanmasıyla, zaman ve mekan kısıtlaması olmadan spekülatif ve kriminalize olmuş içeriklerin paylaşım hızı artmıştır. Bu dipsiz dijital medya kuyusunda, misenformasyon ve dezenformasyon paylaşımlarını oluşturan ve yayan şüpheli şahıslar dışında, iletilerden zarar gören mağdurlar ve toplum vicdanı da bulunmaktadır. Paylaşımların potansiyel yıkıcı etkisi ve salgının oluşturduğu belirsizlik, Gustave Le Bon'un deyimi ile bireyleri telkine açık hale getirmiştir (Le Bon, 2003, s.17; Köchler ve Demir, 2013, s.240). Misenformasyon ve dezenformasyonun gücüyle dolaşıma sunulmuş asılsız tedavi bilgileriyle hayatlarını tehlikeye atan kişilere ve dijital ortam örgütlenmeleriyle kamu güvenliği aleyhine kitlesel eylem çağr1ları yapan hesap ve paylaşımlara rastlanmıştır. Çoklu sanal ortam kullanıc1ları tarafından yakından bilinen bu olumsuz vaka örnekleri, kanuni işlemleri yapmakla yetkili tüm birimlerin ve polisin öncelikli mücadele alanı haline gelmiştir.

Araştırmada kitle tutumlarını yansitan ve yoğun olarak kullanılan sosyal medya platformlarındanTwitter seçilmiştir. 28 örnek vaka; Covid-19 sürecinin ilk periyodunu ve hastalıkla mücadele koşullarının toplum tarafından yaşanarak öğrenildiği dönemi kapsadığından, tepkisel-kasıtlı-bilinçsiz-provakatif içerikli misenformasyon ve dezenformasyonlar, toplumsal paranoya hakkında da ipuçları vermektedir. Twitter örneklemleri dönemsel endişeleri yansıttığı gibi kullanıcıları istemli veya istemsiz suçun paydası ya da mağduru olmalarına neden olmaktadır. Suç sosyolojisi açısından dijital ortam kullanıcılarının Covid -19 bağlamında içinde bulundukları koşulları; savunmasızlık, mağduriyet, düzensizlik ve toplumsal kaygı kuramları ile açıklamak yerinde olacaktır (Öztürk, 2015, s.255). Rader, Cossman ve Porter (2012) savunmasızlık kuramında, sosyal açıdan kendilerini savunmasız ve incinebilir görenlerin suç korkusunun daha yüksek olduğunu belirtirken, Greenberg ve Ruback, (1992) mağduriyet kuramiyla; direkt veya dolaylı yoldan suç mağduru olanların ve kendisi suça maruz kalmasa da suç eyleminden haberdar olanların, endişe duydukların ifade etmektedir. 
Skogan ve Maxfield (1981) düzensizlik kuramında, herhangi bir psikolojik ya da fiziksel nedenle kendini toplumdan soyutlayan ve ikametlerine kapanan bireylerin, anksiyete atakları yaşayabileceklerine işaret ederken, Başıbüyük ve Karakuş (2010) toplumsal kaygı kuramıla; sosyal kontrol mekanizmalarının etkisiz kalması ve sosyal dayanışma zayıflığı bireylerde suça maruz kalma kuşkusu oluşturduğunu vurgulamaktadır. Kuramlarla betimlenen suç ilintili misenformasyon ve dezenformasyonlar, dijital ortam dinamiklerindeki hareketliliği ve heterojen yapının oluşturduğu endişe duygusu, Covid-19 salgını sürecinde daha da kuvvetlendirmiştir. Kitlesel manipülasyon ve provokasyon amaçlı paylaşımlar, pandemiye karşı topyekûn verilen mücadeleyi itibarsızlaştırmayı amaçlarken, kurumların enerjilerinin de gereksiz tüketilmesine neden olmaktadır. Kamu güvenliğine zarar verilmemesi ve suç işleyenlerin adalete teslim edilmesi için, bu türden hesap ve paylaşımlarla ilgili sanal devriyeler tarafından gözlem ve takip yapılarak gerekli soruşturmalar sürdürülmektedir.

Çalışmada koronavirüs salgını kapsamındaki misenformasyon ve dezenformasyon suçlarının analizi odak noktayı oluşturmakla birlikte, genel anlamda dijital medyanın da eleştirisi yapılmaktadır. Dijital ortamlarda yaşamsal ve sosyal ihtiyaçlar karşılanmakta ve toplumun her katmanı tarafından yoğun olarak kullanılmaktadır. Rasyonel bir yaklaşımla gerçek dünya suçlarının, büyük bir bölümünün çoklu sanal ortamlarda işlendiği gözlenmektedir. Sanal platformlarda bireysel ve örgütlü suç işleme biçimleri gündemi belirleyen olaylara göre çeşitlenmektedir. Suç odakları dijital medya açıklarını kullanarak, ilgi uyandıran ve kötüye kullanmaya uygun olan her konuyu istismar etmektedirler. Ayrıca ağ teknolojilerinin getirdiği yeniliklerle, dijital ortamlara özgü suçların da azımsanmayacak ölçekte olduğu bilinmektedir. Her dijital dokunuşun mutlaka bir dijital iz bıraktığı düşünülerek işlem ve paylaşım yapılmasının, suçtan uzak kalmanın temel parametresini oluşturduğu unutulmamalıdır.

Dijital medyanın işlerliği, kullanımı ve sınırları konusunda kurumsal ve ulusal farklılıklar, koronavirüs salgınında infodemiyle mücadelede başarıya oldukça sınırlamaktadır (Kırık, Var, Özkoçak ve Darıcı 2020, s.53). Asılsız ve zararlı paylaşımlara verilen karşılık, bireysel şikâyetlerle ya da kamu hukukunu ihlal eden ve karşlığında cezai müeyyide bulunan olaylarla sınırlı kalmaktadır. Binlerce paylaşımın, aynı anda birçok sanal platformda paylaşıldığı dikkate alındığında otomatik bir denetim mekanizması oluşturulmadan 
misenformasyon ve dezenformasyonun önüne geçilmesi mümkün görülmemektedir (Yanık, 2017, s.365). Çok merkezli ve makro kaynaklı bir sisteme sahip dijital ortam, yapısal sorunları bakımından eleştirilmektedir. Ayrıca denetimsiz ve kontrolsüz bu mecralarda, salgın sürecinde suç oluşturan paylaşımların yayılması da kullanıcıları tedirgin etmektedir. Koronavirüs kapsamında eleştiri konusu olan sanal ortam sakıncalarının, başka bir salgında ya da toplumu yakından ilgilendiren tehlikeli bir olayda nüksedeceği aşikârdır. Bu bakımdan dijital medyanın toplumsal zararlı göz ardı edilmeden, kullanıcların sanal ağları kullanırken gerekli bireysel tedbirleri alması gerekmektedir.

Suça dönüşen misenformasyon ve dezenformasyon paylaşımlarının tespit edilmesinde ve alg1 yönetimi hedefli iletilerin belirlenmesinde deneyimli uzmanların perspektifleri önemli rol oynamaktadır. Dijital polislik uygulamaları proaktif ve reaktif olarak sürdürülmektedir. Ancak dijital medya grift ilişkilerin yaşandığı ve her zaman diliminde suç ile karşılaşılan bir ortama doğru evrilmektedir. Bu ortamlar suç işlenmesini kolaylaştırdığından, üretilen ve tüketilen iletilerde suçun bir parçası olmamaları için, kullanıcıların sorumlu hareket etmelerini zorunlu kılmaktadır. Covid-19 salgınının popüler kavramı olan yeni normalin istismarına yönelik davranışlar ve paylaşımlar, yeni mücadele yöntemleri ile karşılanmasını zorunlu kılmaktadır.

Bu bağlamda polis sanal devriyeler ile yeni bir suç alanı haline gelen dijital dünyada kontrollerini sürdürmektedir. Polisin görevi kapsamındaki tüm iletiler, ilk dolaşıma sunulduğunda belirlenmekte, dijital ortamlarda paylaşıldıkça kullanıcı tespiti ve doğruluğu teyit edilmek üzere sanal devriyeler tarafından defalarca kontrol edilmektedir. Açık kaynak istihbaratı içeriğindeki bu veriler, gerçek dünyada görev alan polislerce değerlendirilmekte, suçun engellenmesi ve oluşan suçun durdurulması amacıyla kullanılmaktadır. Polisin tekil çabaları ve sosyal platformların yasal boşluktan yararlanarak eşgüdüm sağlamamaları çevrimiçi suçların çoğalmasına, etkisini arttırmasına ve suça müdahalede zaman kaybına neden olmaktadır. Bu bakımdan suça dönüşen misenformasyon ve dezenformasyonlara karşı dijital bir filtre oluşturmak amaciyla, sanal ortamların ara yüzlerinde ve sosyal medya platformlarında, resmi kurumların da paydaş olabileceği bir "Güvenlik Portalı" oluşturulması, çalışmanın yazar görüşünü yansıtmaktadır. Çalışmanın sunduğu kanaat ve tavsiyesinin dikkate alınmasıyla gerçekleştirilecek bir "Güvenlik Portalı" düzenlemesinin, bu türden paylaşımlarla mücadelede etkili olacağ değerlendirilmektedir. 
Bununla birlikte dijital mecralarda, kullanıcların suç ilintili etiketleme yaptıkları paylaşımların ihbar niteliği taşıması, son kullanıc ile etkileşim sağlanması ve etkinliğin arttırılması amacıyla, doğrudan Güvenlik Portalına gönderilmesini sağlayacak şekilde düzenleme yapılması da kullanıcıları çözüm ortağı haline getirecektir. Suç içerikli misenformasyon ve dezenformasyonların engellenmesinde ve sanal devriye faaliyetlerine katkı sunulmasında kullanıc1ların etkin rol alması, öz denetimin oluşturulmasında ve dijital ortamların suçtan arınmasında önemli bir adım olacaktır. Milyonlarca kullanıcıyı sanal devriye operatörüne dönüştüren bu düzenleme; yanlış, tahrif edilmiş, aldatıcı ve yanıltıc bilgilerle toplumsal yaşamı olumsuz etkileyen, kitleleri mobilize etmeyi ve kaos oluşturmayı hedefleyen paylaşımlara, hızlı ulaşmaya ve gecikmeksizin hukuksal işlemlerin yapılmasına olanak sağlayacaktır. 


\title{
EXTENDED ABSTRACT
}

\section{Digital Misinformation and Disinformation from a Policing Perspective: An Analysis in the Context of the Covid-19 Case Study}

\author{
Atalay Bahar \\ General Directorate of Security
}

In the research, misinformation and disinformation cases that have turned into crimes from Twitter posts about the Covid-19 outbreak between March 11 and June 1, 2020 are discussed. This descriptive field study, with qualitative and observational data, covers the dates between the first day of the Covid-19 case and the first day of the new normal. In the study, which is limited to the Istanbul-based cases reached as a result of the police operations, the contribution of digital policing towards the production motivation and prevention of the content of the misenformation and disinformation turned into crime is revealed. According to the expert selection principles of Iriste and Katane (2018, p.77, 78), experts from the Istanbul Police Department, Department of Combating Cyber Crimes were determined in order to evaluate the 28 Twitter posts containing misinformation and disinformation, which are evaluated as a crime for this purpose. The 7-hour focus group meeting with experts with professional experience was recorded and analyzed by taking notes.

The concepts of misinformation and disinformation, which constitute the basic axis of the study, have been expressed authentically by using various definitions in the literature. Messages in the scope of misinformation are accepted by users as real and shared regardless of their source. Disinformation sharing is; falsified or unrealistic information consists of incomplete or biased posts. These contents aim to create the desired and expected perceptions of the users with their manipulative features.

When misenformation and disinformation crimes determined with expert opinions are evaluated together, it is understood that the users share sloppy and careless sharing due to the psychological shaking in social networks during Covid-19 process. This anxiety situation stems from the fact that existen- 
tial anxieties affect individual attitudes and behaviors at critical levels according to the Terror Management Theorists (Greenberg, Pyszczynski and Solomon, 1986; Solomon, Greenberg and Pyszczynski, 2004). Fear of death and risk of contagion cause dread processes (Doğulu \& Uğurlu, 2015, p. 42). The motivation to protect against Covid-19 and the challenge of epidemic disease cause conscious or unconscious users to participate in misenformation and disinformation crimes in digital environments.

The restriction of natural life conditions in the context of the coronavirus outbreak, the low threshold of meeting the crisis, and the concept of lost time with developing technology have changed the way of individuals exist in digital media. In this challenging process called by the authorities as the New Normal, the time of the individuals who become isolated with digital shrinkage in digital networks has increased (Kuss and Griffiths, 2011, p. 3534; Güleryüz, Esentaş, Yıldız, Güzel, 2020. p. 33). In addition to the proliferation of shares pointing to socio-psychological breakdowns, the urge to stand out in digital media is also strengthened. Sharing with the idea of "I am in social networks, no matter how I am, I will not forget myself or everyone writes something, I will write" finds a response as misenformation and disinformation crimes.

Another digital media crime that the police decipher with virtual patrol is misenformation and disinformation targeting mass movements. Keyboard heroes, who benefit from anonymous accounts and profiles or various digital media deficits, aim to mass action and provocation by reaching high shares in an organized organization in a short time (Bağcl, 2016, p. 1033). These purposeful posts, made with the feeling of inaccessibility and seen as the background organization in the digital world, consist of manipulated information and challenges. However, experts observe that users who spread messages with obvious signs of crime regret when they understood the seriousness and legal dimensions of the situation during the investigation phase. Focus group interviews conducted through the samples reveal that digital media allow for diversification of individual and mass crime and hiding of criminals. In this context, it is necessary to eliminate the uncontrolled by making legal arrangements in a way to prevent the misuse of digital channels of new normal measures that format natural life.

Institutional and national differences in the functioning, use and limits of digital media limit success in combating infodemia in the coronavirus outbreak (Kırık, Var, Özkoçak \& Darıcı 2020, p. 53). The response to unfounded 
and harmful shares is limited to individual complaints or events that violate public law and which have criminal penalties in return. Considering that thousands of shares are shared on many virtual platforms at the same time, it is not possible to prevent misenformation and disinformation without creating an automatic control mechanism (Yanik, 2017, p. 365). Digital media is evolving into an environment where grippy relationships are experienced and crime is encountered at all times. Since these environments facilitate crime processing, they require users to act responsibly so that they are not a part of the crime in the messages produced and consumed. Behaviors and sharing of abuse of the new normal, which is the popular concept of Covid-19 outbreak, make it compulsory to be met with new methods of struggle.

In this respect, in order to create a digital filter against misinformation and disinformation that turn into crime, creating a "Security Portal" in the interfaces of virtual environments and social media platforms, where official institutions can also be stakeholders, reflects the author's opinion. It is considered that a "Security Portal" arrangement to be implemented by taking into account the opinions and recommendations of the study will be effective in combating such sharing. In addition to this, arrangements in digital media to ensure that the posts that users make criminal-related tagging are notices, and that they are sent directly to the Security Portal in order to interact with the end user and to increase efficiency, make users solution partners.

The active role of users in preventing criminal misinformation and disinformation and contributing to virtual patrol activities will be an important step in establishing self-control and decriminalizing digital environments. This regulation, which transforms millions of users into virtual patrol operators, will enable fast access and legal action without delay, to mobilize the masses that negatively affect the social life and to create chaos with false, falsified, deceptive and misleading information.

\section{Kaynakça / References}

Acar, Y (2020). Yeni Koronavirüs (COVID-19) Salgını ve turizm faaliyetlerine etkisi. Aksaray Üniversitesi Güncel Turizm Araştırmaları Dergisi, 4(1), 7-21.

Aksakall, G. (2020 April 7). Koronavirüs (Covid-19) salginı ve koronafobi etkisi https://www.guvenliweb.org.tr/blog-detay/koronavirus-covid-19-salginive-koronafobi-etkisi adresinden erişilmiştir. 
Altınışı, İ. (2017). Kayıt dişi ekonomi: İlegal bahis. Selçuk Üniversitesi Sosyal ve Teknik Araştırmalar Dergisi, 13, 239-248.

Barış Pınarı Harekatı aleyhinde 'kaçan sivillerin' fotoğraflarıyla manipülasyon girişimi (2019, October 14). Anadolu Ajansı. https://www.aa.com.tr/tr/baris-pinari-harekati/baris-pinari-harekati-aleyhinde-kacan-sivillerin-fotograflariyla-manipulasyon-girisimi/1613054

Asmundson, G. J., ve Taylor, S. (2020, February 10). Coronaphobia: Fear and the 2019nCoV outbreak. https://www.ncbi.nlm.nih.gov/pmc/articles/PMC7134790/

Aydın, A. F. (2020). Post-truth dönemde sosyal medyada dezenformasyon: Covid-19 (yeni koronavirüs) pandemi süreci. Akademik Sosyal Araştırmalar Asya Studies 4(12), 76-90.

Bağcl, C. (2016). Çevrimiçi toplum ve sanal sosyaliteler: Sosyal medya ve özgür dijital dünyanın yeni esaretleri üzerine sosyolojik bir analiz. Journal Of International Social Research, 9(42),1029-1036.

Başıüyü̈k, O., ve Karakuş, Ö. (2010). Sosyal düzensizlik ve toplum destekli güvenlik politikaları. Sosyoloji Araştırmalan Dergisi, 13(2), 64-97.

BBC. (2020, May 13) .Koronavirüs sözlüğ̈̈: Hangi terim ne anlama geliyor? https://www.bbc.com/turkce/haberler-dunya-52630571 adresinden erişilmiştir.

Bekiroğlu, H. A., ve Hülür, A. B. (2016). Üniversite öğrencilerinin facebook kullanımı ve dijital şizofreni üzerine bir araştırma. ODÜ Sosyal Bilimler Araştırmaları Dergisi, 6(14), 146-175.

Bernard, A. (2020, May 3) 'Corona' günlerinde her 10 kişiden altısı yalan haber paylaşıyor. Diken. http://www.diken.com.tr/podcast-corona-gunlerinde-her-10kisiden-altisi-yalan-haber-paylasiyor/ adresinden erişilmiştir.

Botosova, L. (2019). Tackling Misinformation in an Open Society. Media Literacy and Academic Research, 2(1), 107-111.

Bradshaw, S. ve Howard, P. N. (2018). The global organization of social media disinformation campaigns.Journal of International Affairs, 71(15), 23-32.

Ceng, E. (2018). Algı yönetimi aracı olarak Twitter kullanımına ilişkin siyasal bir analiz. Erciyes İletişim Dergisi, 5(4), 663-689.

Çömlekçi, M. F. (2019). Sosyal Medyada Dezenformasyon ve Haber Doğrulama Platformlarının Pratikleri. Gümüşhane Üniversitesi İletişim Fakültesi Elektronik Dergisi, 7(3), 1549-1563.

Del Vicario, M., Bessi, A., Zollo, F., Petroni, F., Scala, A., Caldarelli, G., ... , Quattrociocchi, W. (2016). The spreading of misinformation online. Proceedings of the National Academy of Sciences, 113(3), 554-559. 
Doğulu, C., ve Uğurlu, N. S. (2015). Dehşet Yönetimi Kuramı üzerine bir derleme. Türk Psikoloji Yazllarn, 18(35), 33-47.

Savclık harekete geçti. Hesaplar birbiriyle bağlantllı (2020, April 10). DHA, Retrieved from https://www.milliyet.com.tr/gundem/savcilik-harekete-gecti-hesaplar-birbiriyle-baglantili-6185736

EGM. (2020, June 6). Siber Suçlarla Mücadele Daire Başkanllğı. https://www.egm.gov.tr/siber/sibersucnedir adresinden erişilmiştir.

EGM. (2020, 6 June). Siber Suçlarla Mücadele Daire Başkanlı̆̆ı. https://www.egm.gov.tr/siber adresinden erişilmiştir.

Eren, V. ve Aydın, A. (2014). Sosyal medyanın kamuoyu oluşturmadaki rolü ve muhtemel riskler. KMÜ Sosyal ve Ekonomik Araştirmalar Dergisi, 16(1),197-205.

Erkan, G. ve Ayhan, A. (2018). Siyasal iletişimde dezenformasyon ve sosyal medya: Bir doğrulama platformu olarak teyit. org. Akdeniz Üniversitesi İletişim Dergisi, 29(2), 202-223.

Ermağan, İ. ve Keskinoğlu, M. (2020, June 9). Yeni medya veri ekosistemi, qüvenlikve siber tehditler: Küresel siyasette Trump seçimi üzerinden trollük. analizi https://tasam.org/Files/Icerik/File/Gelecegin g\%C3\%BCvenigi \%C4\%B0GK 4 EKT (9) pdf c05a3fad-1cb5-416d-9d7bb728f2e698c3.pdf adresinden erişilmiştir.

Esen, H. (2020, June 25). Londra'da bir sokak partisi nedeniyle çlkan olayda 15 polis yaralandr. $\quad$ https://www.aa.com.tr/tr/dunya/londrada-bir-sokak-partisi-nedeniyle-cikan-olayda-15-polis-yaralandi/1889463 adresinden erişilmiştir.

Dünyada Covid-19: İlk 4 ayında neler yaşandı? Salgının seyri ne durumda?. (2020, June 8). Euronews. https://tr.euronews.com/2020/05/04/dunyada-covid-19salg-n-n-ilk-100-gununde-yasananlar-ilk-nerede-ortaya-c-kt-nas-l-yay-ld adresinden erişilmiştir.

Fetzer, J. H. (2004). Disinformation: The use of false information. Minds and Machines, 14(2), 231-240.

Fallis, D. (2015). What is disinformation?. Johns Hopkins University Library Trends, 63(3), 401-426.

Greenberg, J., Pyszczynski, T., ve Solomon, S. (1986). The causes and consequences of a need for self-esteem: A terror management theory. In Public self and private self içinde (s. 189-212). Springer, New York, NY.

Greenberg, M.S. ve Ruback, R.B. (1992). After the crime: Victim decision making. London: Plenum Press.

Güleryüz, S., Esentaş, M., Ylldız, K., ve Güzel, P. (2020). Sosyal izolasyon sürecindeki bireylerin serbest zaman değerlendirme biçimleri: Sosyal medya kullanım 
amaçları ile sosyal medya bağımlılığı ilişkisinin incelenmesi. Focuss Spor Yönetimi Araştırmaları Dergisi, 1(1), 31-45.

Güven, A. (2020). Hakikatin yitimi olarak post-truth: Bir kavramsallaştırma denemesi. Insan ve Insan, 7(23), 20-36.

Iriste, S., ve Katane, I. (2018). Expertise as a research method in education. Rural Environment. Education. Personality,11(2), 74-80.

Kalsın, B. (2020, March 27). Kovid 19dan kacarken dezenformasyona tutulmak. Anadolu Ajansı. https://www.aa.com.tr/tr/analiz/kovid-19dan-kacarken-dezenformasyonatutulmak/1781644 adresinden erişilmiştir.

Kara, T. (2020, Nisan 2). Hindistan'da corona virüs tespiti yapmak isteyen doktorlara dayak. Hürriyet. https://www.hurriyet.com.tr/dunya/hindistanda-corona-virustespiti-yapmak-isteyen-doktorlara-dayak-41484959 adresinden erişilmiştir.

Karlova, N. A. ve Fisher, K. E. (2013). A social diffusion model of misinformation and disinformation for understanding human information behaviour. The Information School, University of Washington, 18(1), 573-579.

Kavaklı, N. (2019). Yalan haberle mücadele ve internet teyit/doğrulama platformları. Erciyes İletişim Dergisi, 6(1), 663-682.

Kayır, O. (2020, April 8). COVID-19 salgını ve yalan haberlerle mücadele. https://dijitalmedyavecocuk.bilgi.edu.tr/2020/04/08/covid-19-salgini-ve-yalan-haberlerlemucadele/ adresinden erişilmiştir.

Kırık, A. M., Var, S. S. A., Özkoçak, Ö. Ü. V., ve Darıcı, Ö. Ü. S. (2020). Pandemi dönemlerinde iletişim ve algı yönetimi: Yeni koronavirüs hastalığı (covıd-19) örneği. Akademik Sosyal Araştırmalar Dergisi, 104(8), 36-57.

Kiraz, E. (2020). Sosyal medyada sahte haberin yayılmasında kullanıcı faktörü. İnönü Üniversitesi İletişim Fakültesi Dergisi, 5(1), 9-24.

Köchler, H., ve Demir, M. (2013). Yeni sosyal medya ve 21. yüzyılda iletişim: Diyalog mümkün mü?. Divan: Disiplinlerarası Çalışmalar Dergisi, 18 (35), 223-241.

Kshetri, N. ve Voas, J. (2017). The economics of "fake news". IT Professional, 19(6), 8-12.

Kuklinski, J. H., Quirk, P. J., Jerit, J., Schwieder, D. ve Rich, R. F. (2000). Misinformation and the currency of democratic citizenship. Journal of Politics, 62(3), 790-816.

Kuss, D. J., ve Griffiths, M. D. (2011). Online social networking and addiction-a review of the psychological literature. International journal of environmental research and public health, 8(9), 3528-3552.

Küçükvardar, M. (2018). Suç olgusunun değişen yüzü: Siber suçlar. International Journal of Information, Technology and Philosophy, 1(2),1-18.

Lanoszka, A. (2019). Disinformation in international politics. European journal of international security, 4(2), 227-248. 
Le Bon, G. (2003). The crowd: A study of the popular mind. England: Dover Publications.

Marwick, A. ve Lewis, R. (2017). Media manipulation and disinformation online. New York: Data \& Society Research Institute.

Nyumba, O. T., Wilson, K., Derrick, C. J. ve Mukherjee, N. (2018). The use of focus group discussion methodology: Insights from two decades of application in conservation. Methods in Ecology and evolution, 9(1), 20-32.

O'Connell, O. (2020, February 23). Koronavirüs salginı sonrası Asya kökenli Amerikalılara yönelik ırkçı saldırılar artt. Indyturk. https://www.indyturk.com/node/136491/dünya/koronavirüs-salginı-sonrast-asya-kökenli-amerikalılara-yönelik-ırkçı-saldırllar adresinden erişilmiştir.

Odemiyoruz. (2020, April 9). Twittter. https://twitter.com/hashtag/ödemiyoruz?src=hashtag dick\&f=live

Oxford Learner's Dictionaries. (2020, June 28) Post-truth. https://www.oxfordlearnersdictionaries.com/definition/english/post-truth adresinden erişilmiştir.

Özcan, M. (2018). Öznenin ölümü: Post-truth çağında güvenlik ve Türkiye. İHH İnsani ve Sosyal Araşttrmalar Merkezi 1(55), 1-12.

PR Outletplus, (2020, June 28) Herkesin dilinde olan bu post- truth nedir?. http://www.proutletplus.com/2020/03/25/herkesin-dilinde-olan-bu-posttruth-nedir/ adresinden erişilmiştir.

Rader, N. E., Cossman, J. S., ve Porter, J. R. (2012). Fear of crime and vulnerability: Using a national sample of Americans to examine two competing paradigms. Journal of Criminal Justice, 40(2), 134-141.

Scheufele, D. A. ve Krause, N. M. (2019). Science audiences, misinformation, and fake news. Proceedings of the National Academy of Sciences, 116(16), 7662-7669.

Sheldon, S., Greenberg, J., ve Pyszcznski, T. (2004). The cultural animal: Twenty years of terror management. Handbook of experimental existential psychology, 13-34.

Skogan, W. G., ve Maxfield, M. G. (1981). Coping with crime: Individual and neighborhood reactions. Beverly Hills, CA: Sage Publications.

Somer, E. ve Öztürk, E. (2021, Mart 20). Corona virüsü değil 'ispirt' öldürdü. Sabah. https://www.sabah.com.tr/yasam/2020/03/20/koronavirus-degil-ispirt-oldurdu adresinden erişilmiştir.

Sönmez, Ü. (2017). Bilişim sistemleri aracilığıyla dolandırıclık suçu. Dicle Üniversitesi Adalet Meslek Yüksekokulu,Dicle Adalet Dergisi, 1(2), 47-68.

T.C Sağlık Bakanlığı. (2020, June 7). Yeni koronavirüs hastalığı (covıd-19) https://covid19bilgi.saglik.gov.tr/tr/ adresinden erişilmiştir. 
Türk Ceza Kanunu. (2004, Ekim 12). Resmi Gazete (Sayı:25611). 24.06.2020 tarihinde https://www.resmigazete.gov.tr/eskiler/2004/10/20041012.htm adresinden erişilmiştir.

Ünal, B. ve Kılınç, İ. (2020). Kovid-19 sürecinde toplumsal kanıksamaya karşı çıkış: The New York Times'ın "100,000 hesaplanamaz kayıp" manşeti. Kastamonu İletişim Araştırmaları Dergisi, 4(2), 1-36.

Wardle, C. ve Derakhshan, H. (2017). Information disorder:Toward an interdisciplinary framework for researchand policymaking. Council of Europe Report DGI 09.

WHO, (2020, 29 June). Coronavirus disease (COVID-19) pandemic. https://www.euro.who.int/en/health-topics/health-emergencies/coronavirus-covid-19/novel-coronavirus-2019-ncov adresinden erişilmiştir.

Vural, Z. ve Bat, M. (2010). Yeni bir iletişim ortamı olarak sosyal medya: Ege Üniversitesi İletişim Fakültesine yönelik bir araştırma. Journal of Yasar University, 5(20), 3348-3382.

Yanık, A. (2017). Sosyal medyada yükselen nefret söyleminin temelleri. Global Media Journal, 8(15), 364-383.

Yayla, M. (2014). Siber savaş ve siber ortamdaki kötü niyetli hareketlerden farkı. Hacettepe Hukuk Fakültesi Dergisi, 4(2), 181-200.

Yegen, C. (2018). Doğru haber alma hakkı ve sosyal medya dezenformasyonunu doğruluk payı ve yalansavar ile tartı̧mak. Erciyes İletişim Dergisi, 5(4), 101-121.

"Koronafobi" virüsten daha hızlı yayılıyor. (2020, May 21) Yeşilay. https://www.yesilay.org.tr/tr/makaleler/koronafobi-virusten-daha-hizli-yayiliyor adresinden erişilmiştir.

Zollo, F. ve Quattrociocchi, W. (2018). Misinformation spreading on Facebook. Complex Spreading Phenomena in Social Systems, 2(3),177-196.

\section{Kaynakça Bilgisi / Citation Information}

Bahar, A. (2020). Polislik perspektifinden dijital misenformasyon ve dezenformasyon: Covid-19 örnek olayı bağlamında bir analiz. OPUS-Uluslararası Toplum Araştırmaları Dergisi, 16(30), 2760-2794. DOI: $10.26466 /$ opus.783266 